\title{
Pola Pembinaan Santri dalam Pengendalian Perilaku Menyimpang di Pondok Pesantren ar-Risalah Kota Jember
}

\author{
Suryadi \\ Institut Agama Islam Negeri (IAIN) Jember \\ surya12@iain-jember.ac.id \\ Maslahatun Nikmah \\ Institut Agama Islam Negeri (IAIN) Jember \\ Maslahatun_muslimah@yahoo.com
}

\begin{abstract}
This article discusses the pattern of fostering deviant behavior that occurs among students. This research took place in Islamic boarding school to become one of the institutions of education that is fairly old in the Indonesian nation. In addition, Islamic boarding schools are also known as institutions to deepen knowledge and foster student morals. Therefore, each boarding school has a different pattern of coaching. This study uses field research (field research) with a descriptive qualitative approach. The aim is to be able to describe the results of the analysis in detail. This problem attracts the attention of the writer to examine the pattern of guidance of students in controlling deviant behavior. Based on the results of the study it can be seen that the factors causing deviant behavior of students are influenced by the family environment, boarding schools/schools and peers. As for the pattern of fostering santri in controlling deviant behavior in the boarding school of arRisalah, the village uses three coaching patterns, namely a preventive pattern, a repressive pattern and a curative pattern. Patterns of prevention are carried out to keep the delinquency from happening. Repressive patterns when students have deviant behavior so there must be consequences for the students. And curative control pattern is given if the pattern of preventive and repressive can not be a solution in controlling deviant behavior of students.
\end{abstract}

Keyword: Coaching behavior, deviations, pesantren ar-Risalah 


\begin{abstract}
Abstrak
Artikel ini mendiskusikan tentang pola pembinaan perilaku menyimpang yang terjadi di kalangan santri. Penelitian ini mengambil lokasi di Pondok pesantren menjadi salah satu lembaga pendidikan yang sudah terbilang tua di bangsa Indonesia. Selain itu, pondok pesantren juga dikenal sebagai lembaga untuk memperdalam ilmu pengetahuan maupun membina akhlak santri. Oleh karena itu, setiap pondok pesantren memiliki pola pembinaan yang berbeda-beda. Penelitian ini menggunakan penelitian lapangan (field reaserch) dengan pendekatan kualitatif deskriptif. Tujuannya adalah agar dapat menguraikan hasil analisis dengan detail. Masalah inilah yang menarik perhatian penulis untuk mengkaji pola pembinaan santri dalam pengendalian perilaku menyimpang. Berdasarkan hasil penelitian dapat diketahui bahwa faktor penyebab perilaku menyimpang santri dipengaruhi oleh lingkungan keluarga, pesantren/sekolah dan teman sebaya. Adapun pola pembinaan santri dalam pengendalian perilaku penyimpang dipondok pesantren ar-risalah, desa Curahkates ini menggunakan tiga pola pembinaan, yakni pola pencegahan (preventive), pola penanganan (represive) dan pola kuratif. Pola pencegahan dilakukan untuk menjaga agar kenakalan itu tidak terjadi. Pola represif ketika santri telah melakukan perilaku menyimpang sehingga harus ada konsekuensi untuk santri tersebut. Dan pola pengendalian kuratif diberikan jika pola prefentif dan represif tidak bisa menjadi solusi dalam pengendalian perilaku menyimpang santri.
\end{abstract}

Keyword: Pembinaan perilaku, penyimpangan, pesantren ar-Risalah

\title{
Pendahuluan
}

Setiap manusia yang baru lahir ke dunia sudah memiliki fitrahnya. Fitrah yang dimaksud adalah fitrah sebagai unsur-unsur dan sistem yang dianugerahkan Allah kepada setiap manusia, unsur-unsur itu mencakup jasmani, rohani dan nafs, dimana fitrah berupa "iman kepada Allah" menjadi inti-nya. Potensi iman dipandang sebagai "inti" karena jika iman seseorang telah berkembang dan berfungsi dengan baik, maka potensi-potensi yang lain (jasmani, rohani dan nafs) akan berkembang dan berfungsi dengan baik pula. Disebutkan dalam kalam Allah surat ar-Ruum ayat 30, sebagai berikut:

Maka hadapkanlah wajahmu dengan lurus kepada agama (Allab); (tetaplah atas) fitrah Allah yang telah menciptakan manusia menurut fitrah itu. Tidak ada 
perubahan pada fitrah Allah. (Itulah) agama yang lurus; tetapi kebanyakan manusia tidak mengetahui. (Q.S ar-Ruum: 30) ${ }^{1}$

Terdapat beberapa pendapat ulama tentang maksud kata fitrah - seperti tertulis pada surat ar-Ruum ayat 30. Ada yang berpendapat bahwa (1) fitrah yang dimaksud adalah keyakinan tentang keesaan Allah SWT. yang telah ditanamkan Allah dalam diri setiap insan. (2) fitrah sebagai penerimaan kebenaran dan kemantaban individu dalam penerimaannya, (3) fitrah sebagai keadaan atau kondisi penciptaan yang terdapat dalam diri manusia yang menjadikannya berpotensi -melalui fitrah itu- mampu mengenal Tuhan dan syariatnya, dan (4) fitrah sebagai unsur-unsur dan sistem yang Allah anugerahkan kepada setiap makhluknya. ${ }^{2}$

Fitrah yang berkembang dengan baik kemudian akan membentuk pribadi yang sehat. Kepribadian yang sehat menurut Islam akan terbentuk manakala dua kebutuhan dasar manusia dapat dipenuhi secara seimbang, yakni kebutuhan jasmani dan rohani. Dalam bahasa M. Utsman Najati, kepribadian yang sehat dikenal dengan term an-nafsul muthmainnah, yakni orang yang fisiknya sehat dan kuat, mampu melampiaskan kebutuhan primernya dengan cara yang halal, dan memenuhi kebutuhan spiritual dengan berpegang teguh pada akidah tauhid, mendekatkan diri kepada Allah dengan menjalankan ibadah dan beramal saleh serta menjauhi perbuatan-perbuatan buruk dan hal-hal yang mendatangkan murka Allah. ${ }^{3}$ Pendapat M. Utsman Najati tersebut berdasarkan pada ajaran Al-Quran, dalam suarat al-Qashash (28): 77, Allah bersabda:

Dan carilah pada apa yang telah dianugerabkan Allah kepadamu(kebahagiaan) negeri akbirat, dan janganlah kamu melupakan bahagianmu dari (keni matan) duniawi dan berbuat baiklah (kepada orang lain) sebagaimana Allah telah berbuat baik kepadamu, dan janganlah kamu berbuat kerusakan di (muka) bumi. Sesunggubnya Allab tidak menyukai orang-orang yang berbuat kerusakan."(Q.S al-Qashash : 77)

Sesuai dengan maqolah yang menyatakan "manusia adalah tempatnya salah dan lupa", manusia tidak selalu menjadi pribadi yang sehat, namun ada kalanya manusia menjadi pribadi yang tidak sehat, yakni pribadi yang tidak mampu mengatur diri dalam hubungannya dengan dirinya sendiri, orang lain dan lingkungannya. ${ }^{4}$ Pribadi yang tidak sehat ini salah satu contoh nyata dalam kehidupan sehari-hari adalah dialami oleh sebagian santri yang melakukan

${ }^{1}$ Al-Quran al-Karim, Departemen Agama Republik Indonesia, Surat ar-Ruum: 30.

2 Anwar Sutoyo, Bimbingan dan Konseling Islam: Teori dan Praktik, (Yogyakarta: Pustaka Pelajar, 2015), 24

${ }^{3}$ Abdul Basit, Konseling Islam, (Depok: Kencana, 2017), 29.

${ }^{4}$ Abdul Hayat, Bimbingan Konseling Quran (Jilid I), (Yogyakarta: Pustaka Pesantren, 2017), 36. 
perilaku menyimpang di pondok pesantren karena aturan yang dibuat oleh pengasuh maupun pengurus telah dilanggar.

Pesantren merupakan lembaga pendidikan Islam yang bersifat tradisional untuk memahami, mempelajari dan mengenalkan ajaran agama Islam dengan menekankan pentingnya moral agama Islam sebagai pedoman hidup sehari-hari. Kehidupan dalam pondok pesantren tidak lepas dari rambu-rambu yang mengatur kegiatan dan batas-batas perbuatan: halal-haram, wajib-sunnah, baikburuk dan dan sebagainya itu berangkat dari hukum Islam dan semua kegiatan dipandang dan dilaksanakan sebagai bagian dari ibadah keagamaan, dengan kata lain semua kegiatan dan aktifitas kehidupan selalu dipandang dengan hukum Islam. $^{5}$

Pesantren sebagai lembaga sosial menampung para santri dari berbagai lapisan masyarakat Muslim, tanpa membeda-bedakan tingkat ekonomi maupun sosial dari orangtuanya.Ada di antara calon santri sengaja datang ke pesantren untuk mengabdikan diri kepada Kyai dan pesantren.Selain itu, ada juga orang tua yang sengaja mengirimkan anaknya ke pesantren dalam menyerahkan sepenuhnya untuk diasuh Kyai. Mereka percaya bahwa Kyai tidak akan menyesatkan. Bahkan sebaliknya dengan berkah Kyai anak tersebut akan menjadi orang yang baik. Juga banyak anak-anak yang nakal atau memiliki tandatanda tingkah laku menyimpang, dikirimkan ke pesantren oleh orang tuanya dengan harapan bisa sembuh dari kenakalannya tersebut ${ }^{6}$.

Mengenai tingkah laku meyimpang yang biasa dilakukan santri, pihak pembina santri seperti para ustad-ustadzah serta pengasuh pesantren telah menciptakan peraturan-peraturan agar anggota pondok pesantren berperilaku sesuai dengan peraturan yang berlaku, tapi pada kenyataannya dalam pondok pesantren Ar-Risalah masih dijumpai santri yang melakukan penyimpangan.

Bentuk penyimpangan perilaku yang dilakukan santri khususnya di Pondok Pesantren Ar-Risalah adalah dengan melanggar tata tertib pondok pesantren, misalnya bolos, berpacaran, tidak sholat berjamaah, menyimpan dan menggunakan barang-barang elektronik (HP, radio, tape), mencuri, keluar pondok tanpa izin alias kabur, merokok, ngepil, mewarnai rambut dan lain-lain. ${ }^{7}$

Berdasarkan hasil pra survey yang dilakukan peneliti, Pondok Pesantren Ar-Risalahyang terletak di Desa Curahkates Kecamatan Ajung Kabupaten Jember merupakan salah satu lembaga pendidikan formal dan non formal. Pada pondok pesantren, pengajaran dilakukan dengan pola pengajaran pondok pesantren tradisional yang hanya mengajarkan ilmu agama Islam dan dengan

${ }^{5}$ Fahrurrozi Dahlan, Sosiologi Pesantren: Dialektika Tradisi keilmuan pesantren dalam merespo dinamika masyarakat (potret pesantren di lombok nusa Tenggara barat) (NTB: IAIN Mataram, 2016), 19.

${ }^{6}$ Babun Subarto, Dari Pesantren Untuk. Umat: Reinventing Eksistensi Pesantren di Era Globalisasi (Surabaya: Penerbit Imtiyaz Surabaya, 2011), 18.

${ }^{7}$ Anis, Wawancara, Curahkates, 11 Desember 2018. 
memberikan pendidikan umum sebagai pendidikan formal, misalnya: madrasah tsanawiyah dan madrasah aliyah ${ }^{8}$.

Berdasarkan wawancara awal, pelanggaran atau penyimpangan yang dilakukan para santri terdapat tiga tingkatan, yakni ringan, sedang dan berat.Tingkatan ringan, contonhnya membuat gaduh, terlambat sholat berjamaah. Sedangkan tingkatan sedang, contohnya tidak melakukan sholat berjamaah, tidak mengaji.Dan untuk tingkatan berat, contohnya mencuri berkalikali, keluar batas pesantren tanpa izin, membawa barang elektronik, minum obat-obat terlarang dan pacaran.pelanggaran tingkatan ringan akan menjadi berat jika sering dilakukan dan Kyai maupun Ibunyai akan hafal santri-santri yang melanggar peraturan tersebut. Pelanggaran tingkatan berat pun sudah beberapa kali terjadi di Pondok Pesantren Ar-Risalah, dan konsekuensinya adalah tidak dinaikkan kelas pada sekolah formalnya dan dikeluarkan dari pondok pesantren'.

Setiap pondok pesantren pasti memiliki aturan dan norma yang harus dipatuhi oleh seluruh warga pondok tidak terkecuali Pondok Pesantren ArRisalah. Peraturan ini tidak lain adalah untuk membiasakan santri hidup disiplin, belajar taat akan peraturan, serta belajar menjalankan ajaran agama sesuai yang disunnahkan atau dicontohkan Rasulullah, seperti sholat berjamaah, menjalankan sholat duha maupun sholat malam, taat kepada guru, jujur, menghargai sesama teman dan masih banyak lagi. Tapi kenyataannya kenakalan santri dengan melanggar peraturan pondok tetap saja terjadi. Dikatakan kenakalan santri karena perbuatan santri yang melanggar norma, yang diberlakukan di pondok pesantren menganggu ketentraman masyarakat pondok pesantren maupun masyarakat sekitar pondok pesantren sehingga diberlakukan takziran sebagai hukuman atas pelanggaran yang dilakukan.

Beberapa contoh takziran yang diberlakukan di pondok putri adalah mengaji di dalem pengasuh, sholat malam, cuci piring dalem dan masih banyak macamnya sesuai jenis pelanggaran yang dilakukan bahkan bisa hingga dikeluarkan dari pondok pesantren. Berbeda dengan pondok putra, di pondok putra bahkan tidak ada lagi hukuman, sehingga meskipun santri putra merokok, membawa HP, tidak sholat berjamaah, membolos mengaji ataupun keluar pondok tanpa izin mereka tidak masalah. Ini disebabkan pengasuh sudah lepas tangan dalam mengontrol santri putra.Peneliti melihat ada sesuatu hal yang tidak lumrah dari kejadian ini.KarenaKyai yang menjadi sosok figur sentral untuk para santrinya sekaligus menjadi sumber pengetahuan keagamaan dan sumber nilainilai yang dianut bagi santri, mengajarkan ilmu pengetahuan keagamaan dan sekaligus menanamkan nilai-nilai spiritual dan akhlak mulia kepada santrinya ${ }^{10}$

\footnotetext{
${ }^{8}$ Observasi, Curahkates, 25 Oktober 2018.

${ }^{9}$ Anis, wawancara, Curahkates, 11 Desember 2018.

${ }^{10}$ Konseling islami, 328
} 
kurang melakukan interaksi aktif dengan santri-santrinya, sehingga hubungan komunikasi santri dengan Kyai terlihat jauh. Selain itu, terlihat pengasuh lebih fokus pembinaan untuk santri putri. Secara metodologis penelitian ini menggunakan metode kualitatif dengan pendekatan deskriptif. Adapun pengertian metode penelitian kualitatif merupakan metode penelitian yang digunakan untuk meneliti pada kondisi obyek yang alamiah, dimana peneliti adalah sebagai instrumen kunci, serta hasil akhir lebih menekankan makna dari pada generalisasi. ${ }^{11}$ Pendekatan ini dipilih karena untuk mendeskripsikan semua bahan penelitian baik dari wawancara, observasi, dan dokumentasi.

\section{Hasil dan Pembahasan}

\section{Faktor Penyebab Perilaku Menyimpang Santri Di Pondok Pesantren Ar- Risalah Kota Jember}

Berdasarkan temuan penelitian bahwa ada beberapa faktor yang menyebabkan perilaku menyimpang santri di Pondok Pesantren Ar-Risalah yaitu lingkungan keluarga, teman sebaya, dan lingkungan pesantren. berikut:

Berdasarkan deskripsi penelitian diatas maka diperoleh data sebagai

1. Lingkungan Keluarga

Anak hidup dan berkembang permulaan sekali dari pergaulan keluarga yaitu hubungan antara orang tua dengan anak, ayah dengan ibu dan hubungan anak dengan anggota keluarga lain yang tinggal bersama-sama. Hal ini serasi dengan teori yang diungkapkan Sofyan Willis dalam bukunya bahwa ada banyak hal yang menyebebakan perilaku menyimpang berasal dari lingkungan keluarga, yaitu:

a. Anak kurang mendapatkan kasih sayang dan perhatian orang tua

b. Lemahnya keadaan ekonomi orang tua sehingga kebutuhan anak tidak dapat terpenuhi

c. Kehidupan keluarga yang tidak harmonis (broken home) ${ }^{12}$

2. Teman Sebaya

Hal ini serasi dengan teori menurut Tri Dayakisi bahwa remaja biasanya cenderung mengikuti apa kata teman sebayanya atau teman kelompoknya dari pada orangtua. Maka perlu sekali mendeteksi apa teman itu baik atau tidak. Jika baik maka akan berpengaruh baik. Tetapi jika tidak baik maka akan berpengaruh negatif pada jiwa remaja itu.

${ }^{11}$ Sugiyono, Memahami Penelitian Kualitatif (Bandung: ALFABETA, 2014), 1.

${ }^{12}$ Sofyan Willis, Remaja dan Masalahnya, 99. 
Sesuai sabda Nabi Muhammad SAW berikut:

"Seseorang itu berdasar agama temannya, oleh karena itu hendaklah seorang di antara kalian memperbatikan siapa temannya"."

3. Lingkungan Pesantren

Menilik dari sosiologi kepesantrenan, tujuan utama terbentuknya pesantren, diantaranya adalah membimbing anak didik (santri) untuk menjadi manusia yang berkepribadian Islam dan mempunyai ilmu agama, sehingga sanggup menjadi mubaligh Islam dalam masyarakat sekitar melalui ilmu dan amalnya. Di samping itu, tujuan khusus dibentuknya sebuah pondok pesantren adalah mempersiapkan anak didik (santri) untuk menjadi orang alim dalam ilmu agama yang diajarkan oleh kyai, guru/ustadz yang bersangkutan, serta mengamalkannya dalam masyarakat. ${ }^{14}$ Sehingga bisa disimpulkan bahwa pesantren merupakan tempat pendidikan kedua setelah rumah tangga.

Lingkungan pesantren atau sekolah akan menjadi penyebab munculnya perilaku menyimpang menurut B. Simandjuntak menyebutkan beberapa faktor yakni sebagai berikut:

a. Pendidikan yang kurang menanamkan tingkah laku yang sesuai dengan alam sekitar yang diharapkan pesantren.

b. Menurunnya wibawa seorang guru/ustadz.

c. Pengawasan yang kurang efektif dalam pembinaan berpengaruh dalam domain efektif, konasi, konisi dari guru/ustadz.

d. Kurangnya pemahaman terhadap remaja dari pesantren.

e. Kurangnya sarana penyaluran waktu senggang.

f. Ketidaktahuan guru/ustadz dalam menangani masalah remaja, baik dalam segi pendekatan sosiologis, psikologis maupun pedagogik.15

\section{Pembinaan Santri dalam Pengendalian Perilaku Menyimpang di Pondok Pesantren Ar-Risalah Kota Jember}

\section{Pola Prefentif Perilaku Meyimpang Santri di Pondok Pesantren Pesantren ar-Risalah Kota Jember}

Berdasarkan temuan peneliti bahwa Pondok Pesantren Ar-Risalah kelurahan Curahkates Kabupaten Jember melakukan beberapa hal dalam mencegah terjadinya perilaku menyimpang pada santri, antara lain sebagai berikut:

${ }^{13}$ Mu'awanah, Bimbingan Konseling Islam, 79-80.

${ }^{14}$ Fahrurrozi Dahlan, Sosiologi Pesantren: Dialektika Tradisi keilmuan pesantren dalam merespo dinamika masyarakat (potret pesantren di lombok nusa Tenggara barat),2.

15 Adon Nasrullah Jamaludin, Dasar-dasar Patologi Sosial, (Bandung: CV. Pustaka Setia, 2016), 120. 


\section{Melakukan Pengontrolan}

Berdasarkan temuan peneliti ada kebijakan penempatan pengurus di kamar-kamar santri agar memdahkan mengontrol.

Hal ini senada dengan Ndraha, dikatakan bahwa kontrol dapat dilakukan oleh siapa saja yang berkepentingan terhadap suatu organisasi atau kelompok masyarakat. Kontrol sering diterjemahkan sebagai pengawasan atau pengendalian apapun baik itu perkataan yang diucapkan sampai perbuatan yang dilakukan, sehingga di harapakan adanya kontrol menjadi salah satu nilai dalam masyarakat dan sebagai pembatas ruang lingkupnya. Pada hakikatnya dalam kehidupan masyarakat perlu ada keseimbangan, supaya kehidupan masyarakat tercipta suasana tertib, aman dan damai sesuai dengan tujuan hidup bersama ${ }^{16}$.

2. Mengistiqomahkan Sholat Tahajud dan Tasbih.

Berdasarkan temuan peneliti ada kegiatan sholat tahajud setiap malam sesuai dengan jadwal yang telah dibuat oleh pengurus. Kebijakan pengurus tersebut serasi dengan teori Abdul Hayat dalam bukunya bahwa sholat tahajud adalah sebagai media untuk memohon pertolongan Allah untuk kekuatan jiwa, keteguhan hati dan untuk kesuksesan dan kemuliaan hidup ${ }^{17}$. Firman Allah Swt. dalam Q.S al-Isra: 79, sebagai berikut:

Dan pada sebahagian malam hari bersembabyang tahajudlab kamu sebagai suatu ibadah tambahan bagimu: mudah-mudahan Tuhan-mu mengangkat kamu ke tempat yang terpuji." (Q.S al-Isra: 79)

Mengerjakan sholat tahajud adalah sangat mulia sebab sholat tahajud adalah pekerjaan orang-orang sholeh. Sholat tahajud ini sangat dianjurkan untuk dikerjakan oleh seluruh santri jika menginginkan perbaikan dalam segala aspek kehidupan $^{18}$.

Berdasarkan temuan peneliti setiap malam Jumat Bu Nyai mewajibakan santri untuk melaksanakan Sholat Tasbih, yakni dilakukan ba'da Sholat Isya secara berjamaah. Kebiajakan tersebut serasi dengan Fadhilah Shalat Tasbih yang disampaikan oleh Sulaiman al-Kumayi lainnya adalah:

a. Diampuni dosa.

b. Dapat membentuk pribadi yang kuat.

c. Terkabul segala doa. ${ }^{19}$

${ }^{16}$ Ndraha, Talizidhuhu, Budaya Organisasi(Jakarta: Rineke Cipta,2003), 197.

17 Abdul Hayat, Bimbingan Konseling Qurani jilid II, 127.

18 Ibid., 130.

19 Rika Bekti Lestari, "Persepsi Santri Terhadap Hadis Tentang Salat Tasbih Dan Implementasinya (studi kasus pondok pesantren putri Tahaffudzul Quran Purwoyoso Ngaliyan Semarang", (Skripsi, UIN Walisongo, Semarang, 2015), 39. 


\section{Tirakat Puasa}

Puasa merupakan suatu amalan yang dilakukan umat muslim dari masa ke masa sehingga menjadi suatu amalan yang tidak bisa dilepaskan di dalam kehidupan sehari-hari. Puasa yang dilaksanakan umat muslim tidak hanya yang bersifat wajib sebagaimana yang ditemukan di dalam Alquran tetapi juga bersifat sunnah yang dapat menambah pundi-pundi amal kebaikan dihadapan Allah Swt. ${ }^{20}$

Puasa sunnat adalah puasa yang dilaksanakan pada hari-harisepanjang tahun, kecuali hari-hari yang dilarang untuk berpuasa.Puasasunnat ini juga memiliki harihari yang ditentukan. Selain dari pada itu,puasa sunnat ini di bagi menjadi beberapabagian, diantara sebagai berikut:
a. Puasa Daud
b. Puasa Senin-Kamis
c. Puasa Enam Hari di Bulan Syawal
d. Puasa Hari Putih
e. Puasa Arafah
f. Puasa Asyuro
g. Puasa Sya'ban ${ }^{21}$

4. Memberikan pendidikan ilmu agama melalui pengajian kitab.

Hal ini serasi dengan teori yang diungkap Saiful Akhyar Lubis dalam bukunya bahwa pondok pesantren sebagai lembaga pendidikan Islam, mengandung makna bahwa titik pusat pengembangan keilmuan di lembaga ini adalah ilmu-ilmu keagamaan. Sehingga perlu diingat di samping membuka sekolah umum, tetap harus menyelenggarakan pendidikan madrasah dan pengajian kitab-kitab klasik, terutama diperuntukkan bagi santri yang tidak memasuki sekolah umum. ${ }^{22}$

Zamakhsyari Dhofier dalam bukunya mengelompokkan pengajian kitab Islam klasik ke dalam elemen-elemen pesantren yang harus ada selain pondok, masjid, santri dan kyai. Dikatakan dalam teorinya bahwa tujuan utama pengajaran kitab Islam klasik ini adalah untuk mendidik calon-calon ulama. Para santri yang tinggal di pesantren untuk jangka waktu pendek (misalnya kurang dari satu tahun) dan tidak bercita-cita menadi ulama, bertjuan untuk mencari pengalaman dan pendlaman perasaan keagamaan. Berbeda dengan para santri yang tinggal bertahun-tahun di pesantren. Tujuan mereka adalah ingin

${ }^{20}$ Zakiah Ulfah, Manfaat Puasa dalam Perspektif Sunnah dan Kesehatan”, (Skripsi, UIN Sumatra Utara, Medan, 2016), 26-31.

${ }^{21}$ Ibid.,

22 Akhyar Lubis, Konseling Islami, 187. 
menguasai berbagai cabang pengetahuan Islam dan mempunyai keinginan yang kuat untuk menjadi ulama ${ }^{23}$.

5. Memberikan sarana dan prasarana untuk santri.

Hal ini serasi dengan teori yang diungkap Sofyan Willis dalam bukunya bahwa dengan lengkapnya fasilitas yang diberikan maka akan dapat digunakan untuk mengisi waktu luang misalnya ketika sekolah formal libur atau mengurangi kebosanan dari rutinitas di pondok pesantren. Di samping itu dapat pula mengembangkan bakat santri dalam rangka menuju hidup berdikari nantinya setelah terjun ke masyarakat. ${ }^{24}$

\section{Pola Represif Dalam Pengendalian Perilaku Meyimpang Santri Di Pondok Pesantren Pesantren Ar-Risalah, Curahkates}

Berdasarkan temuan penelitian bahwa ada beberapa upaya represif yang dilakukan pondok pesantren dalam mengendalikan perilaku menyimpang santri yaitu menegakkan tata tertib dan peraturan Pondok Pesantren Ar-Risalah, penerapan sanksi dan penanganan dengan pendekatan Agama Islam. berikut:

Berdasarkan deskripsi penelitian diatas maka diperoleh data sebagai

1. Menegakkan tata tertib dan peraturan Pondok Pesantren Ar-Risalah

Hal ini serasi dengan teori yang diungkapkan Muh. Iqbal dalam jurnal penelitianya. Menyebutkan bahwa peraturan tata tertib pondok pesantren dibuat untuk menegakkan disiplin, baik untuk pengurus, ustadzah maupun santri. Dengan peraturan tata tertib tersebut, diharapkan adanya stabilitas kenyamanan bersama supaya tidak terjadi kesemrawutan dalam menangani berbagai persoalan yang terjadi. ${ }^{25}$

\section{Penerapan Sanksi}

Hal ini serasi dengan teori yang diungkapkan Muh. Iqbal dalam jurnal penelitianya bahwa perilaku menyimpang yang berulang-ulang kali terjadi setelah berbagai upaya dilakukan untuk mencegah namun ternyata terjadi lagi maka pengurus dan pengasuh melakukan tindakan berupa penerapan sanksi, tentunya dengan tujuan memberi efek jera kepada pelaku perilaku menyimpang tersebut. ${ }^{26}$

Jadi sanksi yan diberikan pesantren sebagai hukuman para santri yang melakukan perilaku menyimpang, seperti cuci piring di dapur dalem, mengaji Al-

${ }^{23}$ Dhofier, Tradisi Pesantren, 86.

${ }^{24}$ Sofyan Willis, Remaja dan Masalahnya, 137.

25 Muh. Iqbal, "Penanggulangan Perilaku Menyimpang: Studi Kasus SMA Negeri 1 Pomalaa Kab. Kolaka Sulawesi Tenggara”, Lentera Pendidikan, Vol. 17 No. 2 Desember 2014, 239.

${ }^{26}$ Bawazir, Be a Moslem Be a Counselor, 239. 
Quran, sholat tahajud, membakar atau merusak barang yang diberikan ke santri putra dan lain-lain bertujuan untuk memberi efek jera kepada si pelaku. Agar santri yang melakukan perilaku menyimpang tersebut tidak mengulangi kembali. Kalaupun mengulangi lagi akan ada konsekuensi yang lebih berat.

3. Penanganan dengan pendekatan Agama Islam (Konseling Islam)

Hal ini serasi dengan Bimbingan dan konseling Islam merupakan upaya yang diharapkan dapat mendekatkan konseli kepada penciptanya, Allah Swt, serta mengarahkan konseli agar mendapatkan kehidupan yang aman, tentram dan bermakna. ${ }^{27}$

Ada beberapa pendekatan Agama Islam yang dipakai, antara lain sebagai berikut:

a. Teknik konseling dengan sholat

Apabila sholat ini ditegakkan secara benar oleh ummat maka akan terhindar dari perbuatan keji dan mungkar. Beberapa sholat sunnah yang sangat tepat untuk dijadikan teknik konseling dalam rangka membantu konseli untuk mengatasi berbagai kesalahan hidup antara lain adala sholat tahajud, sholat hajad dan sholat duha. ${ }^{28}$

b. Teknik konseling dengan membaca Al-Quran

Bacaan atau membaca ayat-ayt suci Al-Quran bisa dijadikan salah satu teknik konseling Islami. Jadi Al-Quran yang merupakan kitab pedoman dalam kehidupan ummat Islam yang berisi perundang-undangan dalam berbagai aspek kehidupan, juga berfungsi sebagai penyembuh (syifa) dari berbagai penyakit batin, psikologis bahkan fisik, menjadi solusi dari kebingungan dalam mengahadapi berbagai permasalahan hidup dan menjadi penenang hati ${ }^{29}$

c. Teknik konseling dengan zikir

Zikir adalah salah satu teknik terapi dalam konseling Islami. Banyak sekali manfaat dari zikir kepada Allah Swt. yang diterangkan oleh Allah Swt. dalam kitab-Nya, antara lain yaitu: dapat menentramkan hati, mendapatkan ampunan dan pahala yang besar, menghapus keburukan atau dosa, dan memudahkan datangnya pertolongan dari Allah. ${ }^{30}$

\section{Pola Kuratif Dalam Pengendalian Perilaku Meyimpang Santri Di Pondok Pesantren Pesantren Ar-Risalah, Curahkates}

Berdasarkan temuan penelitian bahwa ada beberapa upaya kuratif yang dilakukan pondok pesantren dalam mengendalikan perilaku menyimpang santri

\footnotetext{
${ }^{27}$ Ibid., 6.

${ }^{28}$ Hayat, Bimbingan Konseling Qur'ani (jilid II), 123.

${ }^{29}$ Ibid., 140.

${ }^{30}$ Ibid., 144.
} 
yaitu pembebasan peraturan oleh Pengasuh, tidak dinaikkan kelas, dan dikembalikan kepada orangtua.

Pengendalian kuratif ini dilakukan ketika pola prefentif dan represif tidak membuat efek jera bagi santri yang melakukan perilaku menyimpang. Berdasarkan deskripsi penelitian diatas maka diperoleh data sebagai berikut:

1. Pembebasan peraturan oleh pengasuh

Hal ini tidak serasi dengan teori yang diungkapkan Muh. Iqbal dalam jurnal penelitianya. Ia menyebutkan bahwa peraturan tata tertib pondok pesantren dibuat untuk menegakkan disiplin, baik untuk pengurus, ustadzah maupun santri. Dengan peraturan tata tertib tersebut, diharapkan adanya stabilitas kenyamanan bersama supaya tidak terjadi kesemrawutan dalam menangani berbagai persoalan yang terjadi. ${ }^{31}$

Jadi jika tidak ada penegakkan peraturan utamanya dari Pengasuh maka akan terjadi kesemrawutan, ketidak disiplinan santri, peraturan semakin diremehkan bahkan santri juga merasa tidak dihiraukan lagi oleh Pengasuh.

Selain itu, Akhyar Lubis menyatakan dalam bukunya bahwa di mata santri, peran kyai sebagai pembimbing perilaku/ nilai-nilai spiritual ditempatkan dalam posisi sentral. Para santri akan merasa lebih senang dan bangga apabila memperoleh kesempatan untuk berkonsultasi pada Kyainya. ${ }^{32}$ Namun jika Pengasuh kurang berinteraksi dengan santri maka perasaan itu akan susah dirasakan oleh santri.

Sofyan Willis juga mengungkapkan bahwa persoalan perilaku menyimpang ini tidak dapat diselesaikan hanya melalui ceramah dan pidato, akan tetapi lebih baik jika dengan perbuatan yang nyata (action)..$^{33}$

2. Tidak dinaikkan kelas

Tindakan ini adalah untuk memberikan efek jera kepada santri yang melakukan perilaku menyimpang tersebut. Selain itu, juga bertujuan agar santri merenungi kembali segala perilaku yang telah dilakukan. Sehingga diharapkan bisa memulihkan kembali santri untuk bersikap lebih baik lagi. ${ }^{34}$ Wewenang hukuman berat seperti ini adalah wewenang dari Pengasuh selaku pemilik kebijakan tertinggi.

31 Muh. Iqbal, "Penanggulangan Perilaku Menyimpang: Studi Kasus SMA Negeri 1 Pomalaa Kab. Kolaka Sulawesi Tenggara”, Lentera Pendidikan, Vol. 17 No. 2 Desember 2014, 239.

32 Akhyar Lubis, Konseling Islami: kyai dan Pesantren, 354.

${ }_{33}$ Sofyan S. Willis, Ramaja dan Masalahnya (Bandung: Alfabeta, 2017), 127.

34 Muh. Iqbal, "Penanggulangan Perilaku Menyimpang: Studi Kasus SMA Negeri 1 Pomalaa Kab. Kolaka Sulawesi Tenggara”, Lentera Pendidikan, Vol. 17 No. 2 Desember 2014, 240. 


\section{Dikembalikan kepada orangtua}

Hal ini serasi dengan teori yang diungkapkan Muh. Iqbal dalam jurnal penelitianya bahwa setelah berbagai upaya telah dilakukan kepada santri, ternyata belum menunjukkan perubahan dalam artian pembebasan peraturan dan tidak dinaikkan kelas sudah diterapkan namun belum menunjukkan sikap jera, maka langkah terakhir adalah mengembalikan santri kepada orang tuanya. ${ }^{3 .}$

Selain itu, tindakan ini merupakan tindakan terakhir dalam mengatasi berbagai permasalahan santri. Hal ini dilakukan agar perilaku menyimpang tersebut tidak menjangkiti santri lainnya. ${ }^{36}$

\section{Penutup}

Berdasarkan hasil penelitian yang dilakukan mengenai Pola Pembinaan Santri dalam Pengendalian Perilaku Menyimpang di Pondok Pesantren Arrisalah Kota Jember bahwa dapat disimpulkan beberapa hal sebagai berikut:

Pertama,faktor penyebab perilaku menyimpang di Pondok Pesantren Ar-Risalah Kota Jember adalah: lingkungan keluarga. Seperti kurangnya kasih sayang, broken home dan lemahnya ekonomi orang tua. Teman sebaya, ini karena keseringan santri bersama dengan teman-temannya. Sehingga ketika temannya baik maka Ia akan baik sedangkan jika temannya nakal Ia juga akan terpengaruh nakal. Dan lingkungan pesantren. Seperti: pendidikan yang kurang menanamkan tingkah laku yang sesuai dengan alam sekitar yang diharapkan pesantren, menurunnya wibawa seorang guru/ustadz, pengawasan yang kurang efektif dalam pembinaan berpengaruh dalam domain efektif, konasi, konisi dari guru/ustadz, kurangnya pemahaman terhadap remaja dari pesantren, kurangnya sarana penyaluran waktu senggang dan ketidaktahuan guru/ustadz dalam menangani masalah remaja, baik dalam segi pendekatan sosiologis, psikologis maupun pedagogik

Kedua, pola pembinaan pengendalian perilaku menyimpang di Pondok Pesantren Ar-Risalah terdiri dari tiga pola pembinaan, yaitu pola prefentif, represif, dan kuratif. Pola prefentif dilakukan untuk mencegah terjadinya perilaku menyimpang santri. Dilakukan dengan beberapa upaya, yaitu: melakukan pengontrolan, mengistiqomahkan sholat tahajud dan tasbih, tirakat puasa dan memberikan pendidikan ilmu agama melalui pengajian kitab.

Pola represif dilakukan untuk menangani perilku menyimpang yang telah dilakukan. Ada beberapa upaya yang dilakukan pesantren, yaitu: menegakkan tata tertib dan peraturan, penerapan sanksi, dan penanganan dengan pendekatan Agama Islam.

\footnotetext{
${ }^{35}$ Ibid., 240.

${ }^{36}$ Ibid., 240.
} 
152 | Islamic Counseling: Jurnal Bimbingan dan Konseling Islam, Vol. 3, No. 2, 2019

Pola kuratif menjadi tindakan terakhir ketika pola prefentif dan represif tidak mampu memberikan efek jera untuk pelaku perilaku menyimpang tersebut, yakni dengan beberapa upaya yaitu: pembebasan peraturan oleh Pengasuh, tidak dinaikkan kelas, dan dikembalikan kepada orang tua. 


\section{Bibliografi}

Al-Quran al-Karim, Departemen Agama Republik Indonesia, Surat ar-Ruum: 30.

Bawazir, Djauharah, (2013), Be a Moslem Be a Counselor. Jakarta Timur: Bunyan Andalan Sejati.

Dahlan, Fahrurrozi, (2016), Sosiologi Pesantren: Dialektika Tradisi keilmuan pesantren dalam merespo dinamika masyarakat (potret pesantren di lombok nusa Tenggara barat) NTB: IAIN Mataram.

Dhofier, Zamakhsyari, (2011), Tradisi Pesantren: Studi Pandangan hidup. Jakarta: LP3ES.

Hayat, Abdul, (2017), Bimbingan Konseling Qur'ani (jilid II). Yogyakarta: Pustaka Pesantren.

Hayat, Abdul, (2017), Bimbingan Konseling Quran (Jilid I), Yogyakarta: Pustaka Pesantren.

Jamaludin, Adon Nasrullah, (2016), Dasar-dasar Patologi Sosial, Bandung: CV. Pustaka Setia.

Lestari, Rika Bekti, (2015 ) "Persepsi Santri Terhadap Hadis Tentang Salat Tasbih Dan Implementasinya (studi kasus pondok pesantren putri Tahaffudzul Quran Purwoyoso Ngaliyan Semarang”, Skripsi, UIN Walisongo, Semarang.

Lubis, Saiful Akhyar, (2007), Konseling Islami: kyai dan pesantren. Yogyakarta: elSAQ Press,

Mu'awanah,Elfi. 2012.Bimbingan Konseling Islam: Memahami Fenomena Kenakalan Remaja dan Memilih Upaya Pendekatanya dalam Konseling Islam. Yogyakarta: Teras.

Muh. Iqbal, "Penanggulangan Perilaku Menyimpang: Studi Kasus SMA Negeri 1 Pomalaa Kab. Kolaka Sulawesi Tenggara”, Lentera Pendidikan, Vol. 17 No. 2 Desember 2014.

Ndraha, Talizidhuhu, (2003), Budaya Organisasi, Jakarta: Rineke Cipta.

Sugiyono, (2014), Memahami Penelitian Kualitatif, Bandung: ALFABETA.

Suharto, Babun, (2011), Dari Pesantren Untuk Umat: Reinventing Eksistensi Pesantren di Era Globalisasi,

Sutoyo, Anwar, (2015), Bimbingan dan Konseling Islam: Teori dan Praktik, Yogyakarta: Pustaka Pelajar.

Willis, Sofyan, 2017, Ramaja dan Masalahnya, Bandung: Alfabeta. 
154 | Islamic Counseling: Jurnal Bimbingan dan Konseling Islam, Vol. 3, No. 2, 2019 